\title{
Properties of a Lateritic Red Soil for Pollutant Containment
}

\author{
Maria Eugenia Gimenez Boscov¹, Waldemar Coelho Hachich ${ }^{1}$, Claudio Fernando Mahler ${ }^{2}$, \\ Elisabeth de Oliveira ${ }^{1}$ \\ ${ }^{1}$ University of São Paulo, São Paulo, Brazil; ${ }^{2}$ Federal University of Rio de Janeiro, Rio de Janeiro, Brazil. \\ Email: meboscov@usp.br.
}

Received May 22 ${ }^{\text {nd }}, 2011$; revised July $6^{\text {th }}, 2011$; accepted August $16^{\text {th }}, 2011$.

\begin{abstract}
In many regions of Brazil, lateritic clays are the natural candidates for the construction of compacted clay liners of waste disposal sites because of their availability and appropriate geotechnical characteristics. Lateritic soils have been extensively used in recent decades in dam and road construction, but little is known about the migration of pollutants through compacted layers of such soils. This paper describes the characteristics of a lateritic clay, representing a group of soils of significant occurrence in the State of São Paulo, to be employed in a clay liner of a waste disposal site. Laboratory tests to assess permeability, adsorption and diffusion of six metals through the compacted soil showed that permeability criterion may be met in the field, that the soil presents a modest capacity to retain cadmium and that constituent metal oxides may be dissolved from the soil grains by acidic solutions.
\end{abstract}

Keywords: Compacted Clay Liner, Lateritic Soil, Permeability, Cadmium, Adsorption

\section{Introduction}

There is growing concern in Brazil regarding the problem of disposal of domestic and industrial wastes. Sanitary landfills have been built in most cities in the last decade, but $34 \%$ of the total collected mass of municipal solid wastes (MSW) are still disposed of inadequate landfills or dumped [10]. Industrial conglomerates and large industrial plants are controlled by environmental authorities, but wastes from smaller industries are still co-disposed with solid municipal waste in small municipalities.

International regulations for the design of waste disposal sites adopted in Brazil provide general guidelines, but understanding the peculiarities of Brazilian soils and climate is essential to check the applicability of such regulations to specific sites. Large areas of the country are covered with tropical soils [14], among which the lateritic red clays are natural candidates for the construction of compacted clay liners [5]. Lateritic soils have been extensively used in the last decades in dam and road construction; nevertheless, very little is known about the migration of pollutants through compacted layers of such soils.

The main mechanisms of solute transport through a porous medium are: advection, mechanical dispersion, diffusion, chemical reactions of the solute in the solution, such as radioactivity, and chemical reactions among solute and solids, such as adsorption [9]. Advection, i.e. the movement of solute as it is carried by the water seeping through the soil, and mechanical dispersion, i.e. the mixing that occurs together with advection, are dependent on the hydraulic conductivity of the soil. Diffusion, i.e. the movement of ionic and molecular constituents by their thermal-kinetic energy in the opposite direction of the concentration gradient, is controlled by the diffusion coefficient in the chemical species of the soil. Adsorption, which is a physical-chemical process by which a solute is accumulated in a solid-liquid interface, is essentially due to clay minerals, which are negatively charged because of isomorphic substitution of cations in the silicate or aluminate layers of the crystalline reticule. Other retention mechanisms may occur, such as precipitation, ion complexation and specific adsorption. The capacity of soils for attenuating pollution has been intensively studied in the last thirty years; an important application is the utilization of compacted clay liners in waste disposal sites or waste treatment plants to control subsoil contamination [15].

This paper describes the characteristics of a lateritic clay, representing a group of soils of significant occurrence in the State of São Paulo, to be employed in a clay 
liner of a waste disposal site. Procedures for the geotechnical characterization of a lateritic soil for the performance-oriented design of compacted clay liners are also discussed. A case study is used as an example for the suggested procedures.

\section{Lateritic Soils}

Lateritic clays are natural candidates for the construction of compacted layers of low permeability in Brazil, because of their availability in large areas of the country and current and past use in dam and embankment construction.

As shown in Figure 1, lateritic soils occur all over the country in surface layers of the pedological horizon, from tens of centimeters to 10 meters thick. Important dams, such as Itaparica, Três Irmãos, Juquiá, Poços de Caldas and Itaipu, among others, have been built with lateritic clays [6]. The more granular groups have also been extensively employed in the last decades as material for road bases and subbases in the Southeast, particularly in the State of São Paulo [3].

Lateritic soils were formed by the intensive pedological process called laterization, which comprises leaching of alkali and alkaline-earth metals and decreasing silica content, with concurrent maintenance of stable minerals, such as quartz; presence of clay minerals in advanced degrees of transformation; and accumulation and adhesion of hydrated iron and aluminum oxides to the surfaces of the clay particles [11]. Thus, the clay fraction of lateritic soils is essentially constituted of clay minerals of the kaolinite group and iron and/or aluminum oxides and hydroxides. These components are combined in the form of water-stable popcorn-shaped micro-aggregates. Iron and aluminum, besides covering the surfaces of the clay minerals with consequent reduction of the capacity of water absorption, act as natural cementing agents amongst clay particles.

A peculiar characteristic of lateritic soils is the shape of the compaction curve, which presents a well defined peak at the maximum dry unit weight and a steep slope-

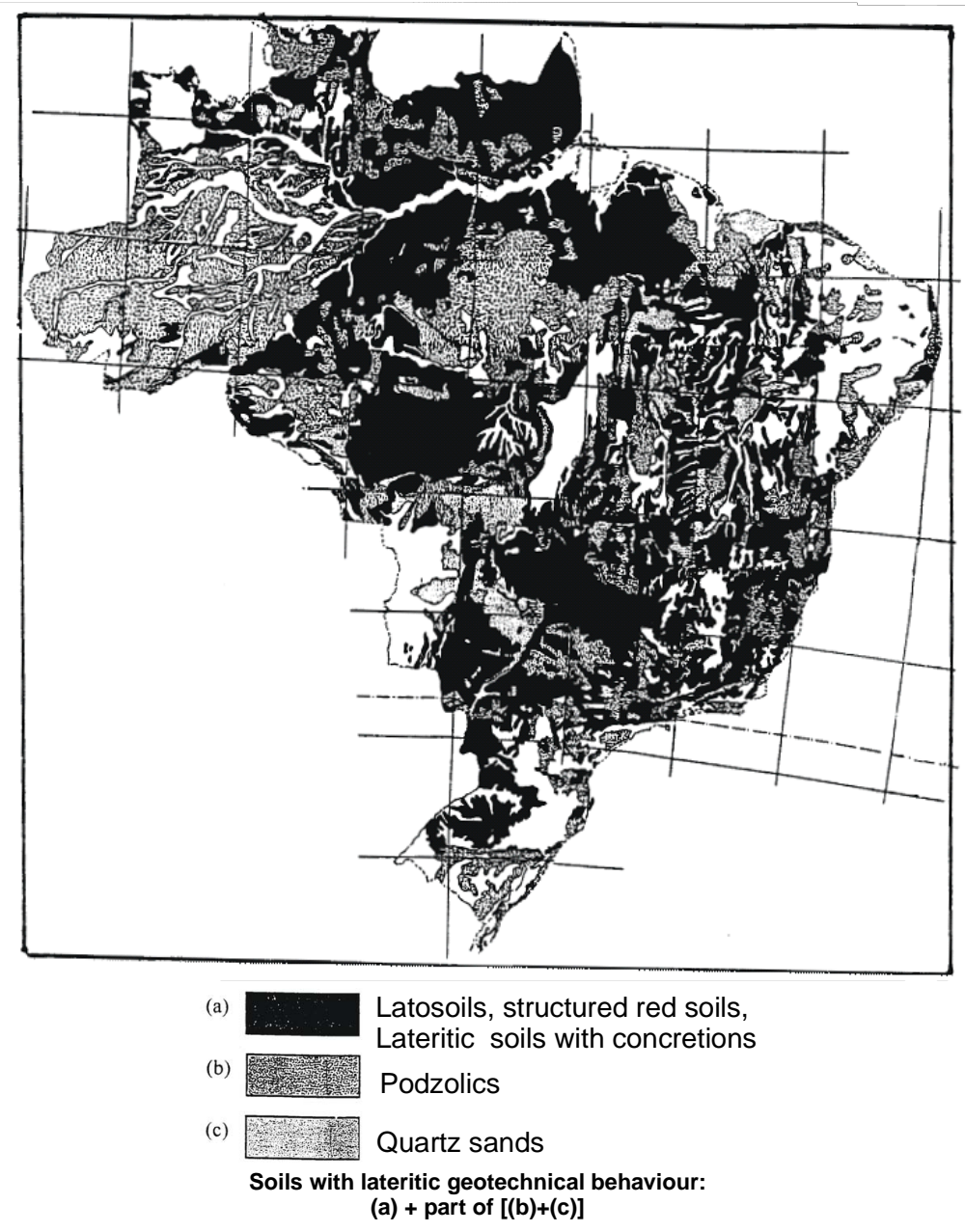

Figure 1. Distribution of lateritic soils in Brazil [14]. 
on the dry side, even for the clayey soils $[3,14]$. A slight deviation in the dry unit weight causes significant changes in resistance, deformability and permeability $[4,14]$. Lateritic clays do not swell nor lose resistance when wet, but shrink significantly by loss of water. Road and dam construction engineers have learned to cope with the development of shrinkage cracks, for example, by means of scarification and recompaction of several centimeters of the embankment surface before placement of a new layer.

\section{Case Study}

Tietê River flows across the metropolitan region of São Paulo and collects wastes from its 18 million inhabitants and 39,000 industrial plants. Every year up to 2 million cubic metres of sediments are dragged from the bottom of the river and disposed of at natural or artificial depressions around the city to minimize the disastrous floods that frequently overwhelm São Paulo. Past studies showed high concentration levels of heavy metals in the sediment pore water [7], originated from non treated domestic sewage and industrial (automotive, metallurgy, chemical, pharmaceutical, textile, among others) effluents discarded in the river [13]; this situation has reversed in the past years by means of environmental control of emissions. A prospective final disposal area was chosen for the research: a former sand borrow pit located in the outskirts of the City, near Guarulhos International Airport, sided by a water course, and exhibiting a shallow water table.

The material dragged from the bottom of Tietê is a black sludge emitting an unpleasant smell, with high concentrations of organic compounds and large amounts of rubbish. After pre-treatment consisting of drainage, open air exposure to enhance organic matter deterioration, sieving, and temporary storage in intermediate disposal areas, the sediments can be classified as uniform fine sand (SP) by the Unified System of Soil Classification, and exhibit a clean appearance, normal colour, and no particular smell.

Biochemical analyses were carried out to determine the concentration of metals, volatile organic compounds, mononuclear and polynuclear aromatics in the pretreated sediments. Solubility and leaching tests conducted according to Brazilian regulations indicated the presence of aluminum, cadmium, iron, manganese, mercury and zinc in concentrations higher than the maximum allowable limits.

For an environmentally safe design a clay liner is considered mandatory to protect the subsoil, as the water level in the prospective disposal area is practically at the surface. Therefore, the study was focused on the behaviour of a compacted clayey Brazilian red soil, a natural candidate for a liner, in relation to the transport of the metal ions detected in excessive concentrations. Permeability, adsorption, and diffusion tests were carried out. It is acceptable to consider pollutant transport through cover, liner and subsoil layers in the aforementioned disposal site as one-dimensional, since the area is large, the subsoil layers fairly horizontal and the water table high.

The soil is a red lateritic clay from the outskirts of the City of São Paulo. 77\% of the total mass of dry soil has diameters smaller than $0.075 \mathrm{~mm}$, and $62 \%$ smaller than $0.002 \mathrm{~mm}$ (ASTM D422). Liquid and plastic limits (ASTM D4318) are 51\% and 34\%, respectively. Soil classification is $\mathrm{CH}$, inorganic clay of high plasticity (ASTM 2487)). A standard Proctor compaction test (ASTM D698) yielded $14.65 \mathrm{kN} / \mathrm{m}^{3}$ and $26.5 \%$ as, respectively, the maximum dry unit weight $\gamma_{\mathrm{dmax}}$ and the optimum water content $\mathrm{w}_{\text {opt }}$ (Figure 2). Primary minerals are quartz, nacrite, kaolinite, gibbsite and hematite.

The soil is naturally flocculated. A sedimentation test performed without the addition of a deffloculant agent indicated that, even after 24 hours immersed in water and dispersed by a mixer, soil particles behave like silt-sized flocks of around $0.01 \mathrm{~mm}$ diametre.

\section{Experimental Procedure}

\subsection{Permeabilty Tests}

The influence of compaction on the permeability coefficient, $\mathrm{k}$, was evaluated, to verify under what conditions $\mathrm{k}$ values lower than $10^{-9} \mathrm{~m} / \mathrm{s}$ could be obtained. Twentyseven specimens were compacted statically at varying

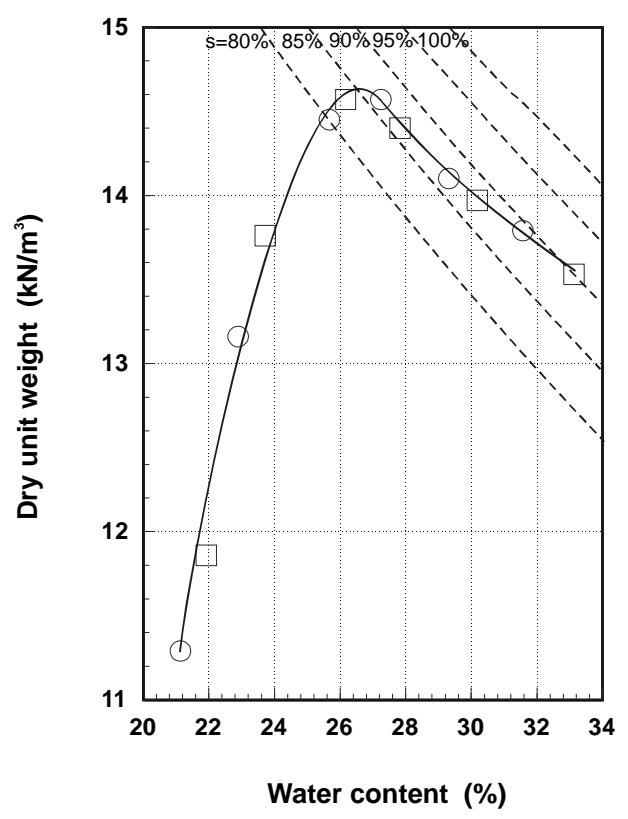

Figure 2. Compaction curve of the red lateritic clay from Sao Paulo (ASTM D). 
moulding water contents, from $\mathrm{w}_{\mathrm{opt}}-2.5 \%$ to $\mathrm{w}_{\mathrm{opt}}+2.5 \%$, and at relative compactions $\left(\mathrm{RC}=\gamma_{\mathrm{d}} / \gamma_{\mathrm{dmax}}\right)$ from $95 \%$ to $103 \%$ ( $\mathrm{w}_{\mathrm{opt}}$ and $\gamma_{\mathrm{dmax}}$ at standard Proctor energy).

Flexible wall permeability tests were performed in triaxial cells using distilled water in a temperature- controlled room at $(20 \pm 2)^{\circ} \mathrm{C}$. Preliminary tests indicated a negligible influence of the applied confining pressure and hydraulic gradients in the measured permeability coefficient, as shown in Figure 3; test duration could therefore be reduced. Meriggi \& Zagollin [12] observed double or triple variations in the permeability coefficient when the confining pressure increased from 100 to $300 \mathrm{kPa}$, and practically gradient-independent permeability coeffcients for hydraulic gradients varying from 10 to 40 .
Tests were carried out until a constant flow rate and permeability coefficient was achieved, which corresponds to saturation equilibrium, i.e. the maximum saturation degree that can be reached by seepage. The permeability coefficient determined in specimens saturated by backpressure represent a maximum limit unlikely to occur in the field. For optimum compaction conditions, the final degree of saturation, between $90 \%$ and $97 \%$, was reached after two pore volumes of flow through the specimen, as shown in Figure 4. In other compaction conditions, corresponding to higher or lower permeabilities, greater or smaller volumes of water, respectively, were needed to reach equilibrium.

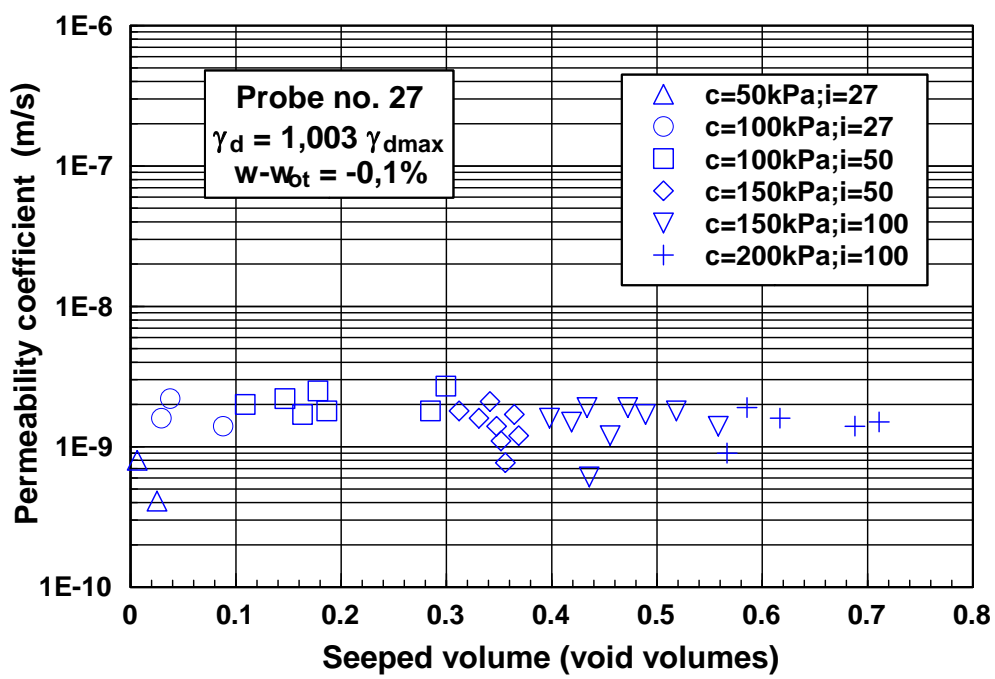

Figure 3. Permeability test with varying confining pressure (c) and hydraulic coefficient (i).

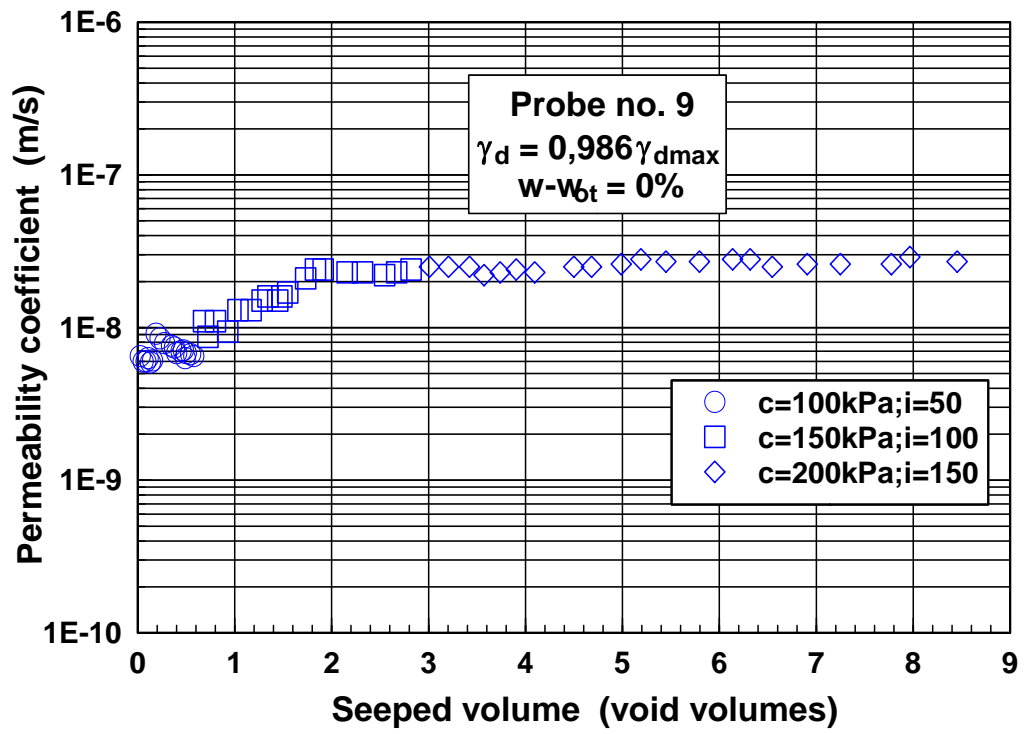

Figure 4. Variation of the measured permeability coefficient during a permeability test. 


\subsection{Compatibility Tests}

In order to check the compatibility of the soil to the leachate, liquid and plastic limits were determined with addition of $1000 \mathrm{mg} / \mathrm{kg}$ (maximum allowable value of pollutant mass per dry mass of soil according to Brazilian regulations) of each metal separately.

\subsection{Diffusion Tests}

Diffusion tests followed the procedure described by Barone, et al. [1]. The specimens were compacted directly in the moulds, and saturated by capillarity and seepage. Saturation was calculated by measuring the specimen weight and volume during the processes of water absorption and seepage. Specimens were then submitted to approximately ten days of diffusion. The diffusion mould had a reservoir for the pollutant solution topping the soil specimen with no possibility for seepage, so that ions were expected to migrate from the solution through the soil, driven only by a concentration gradient. At constant time intervals, samples were taken from the fluid reservoir to monitor the solution composition. Tested solutions were synthetic mixtures of the metals detected in excess in the pore water of Tietê River's sediments with 18 different compositions (different concentrations of each metal and relative proportions of the six metals).

\subsection{Batch Equilibrium Tests}

Batch equilibrium adsorption tests were performed in accordance with USEPA guidelines (1992) [16] with cadmium and mercury solutions. Initially, method A was tested twice for each metal separately, i.e. by varying quantities of soil with equal volumes of the same solution, resulting in different soil/solution ratios but in equal initial concentrations. However, results were poor since the mass of adsorved solute was practically independent of the mass of dry soil. Simultaneously, the mass of manganese liberated in the solution increased with the mass of dry soil, clearly indicating a process of solubilization and/or desorption of manganese from the clay particles, since this metal was not present in the initial solution. The same behaviour was observed for aluminum, iron, and zinc. Tests were again carried out with method B, i.e. equal quantities of soil and equal volumes of solutions with varying concentration, resulting in equal soil/solution ratios but different initial concentrations.

\subsection{Spectrometry of Atomic Emission}

Concentrations of metal ions in the liquid samples of diffusion, dispersion and batch equilibrium tests were determined by spectrometry of atomic emission with induced argonium plasma.

\section{Results}

\subsection{Permeability tests}

The results of permeability tests are shown in Figure 5.

Figure 6 illustrates trends of the variation of the permeability coefficient as a function of moulding water content and dry unit weight based on the test results. The permeability coefficient of the red soil is about $10^{-9} \mathrm{~m} / \mathrm{s}$
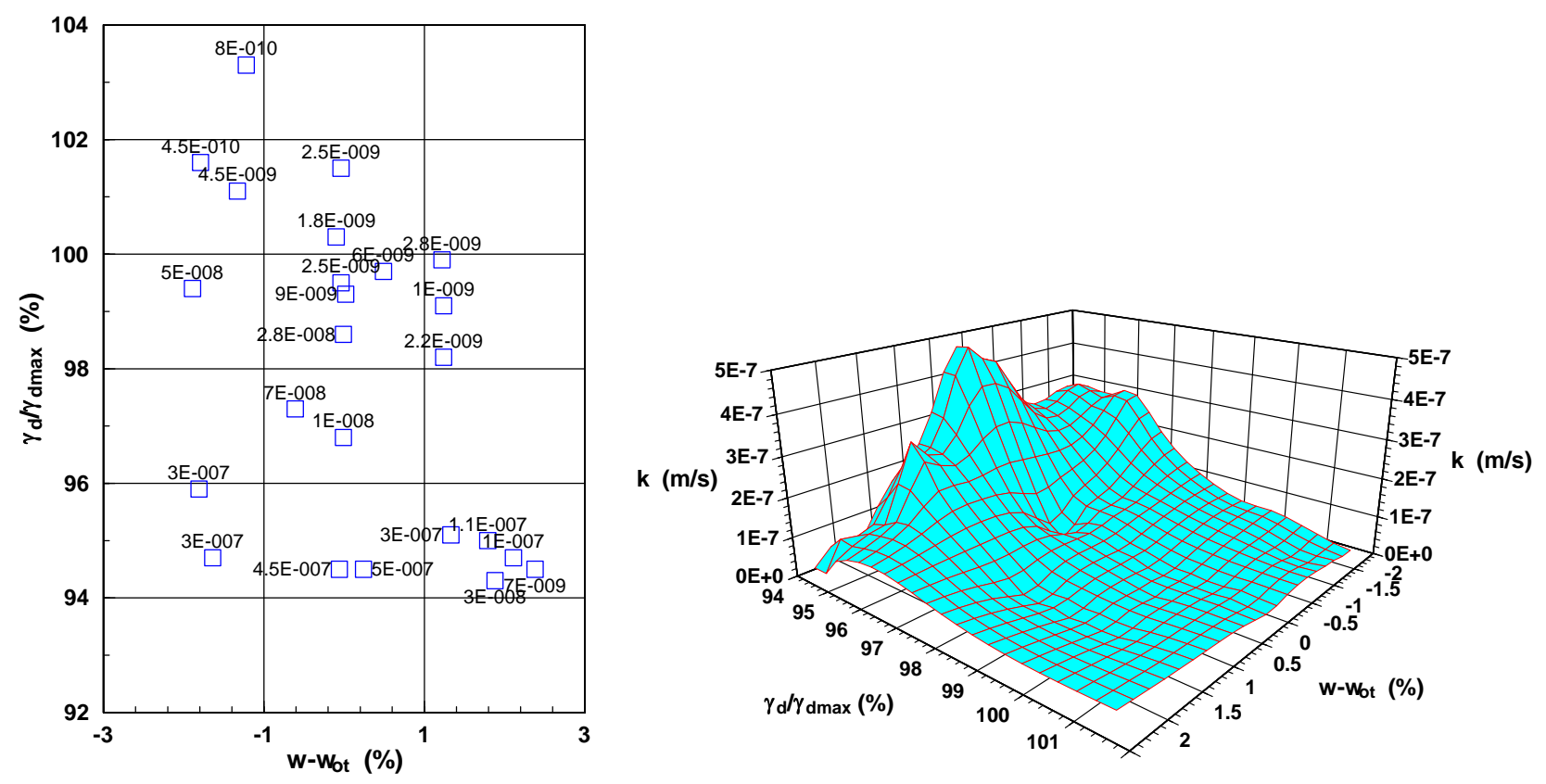

Figure 5. Permeability tests results. 


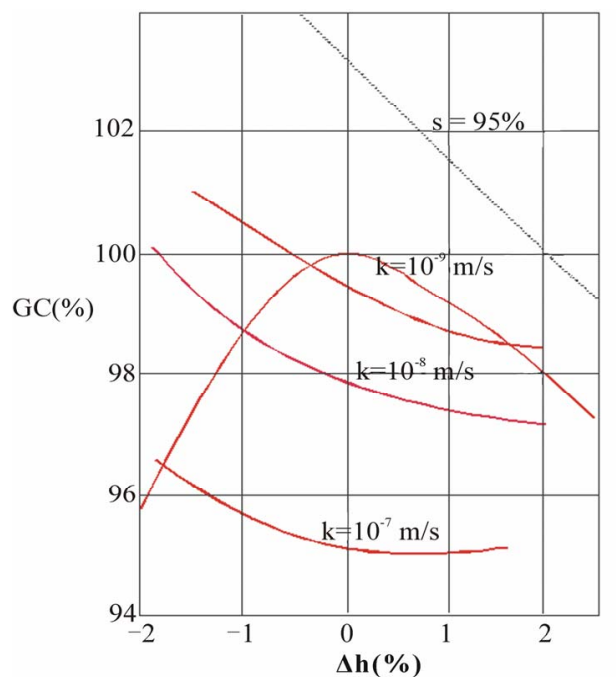

Figure 6. Permeability coefficient as a function of water content and dry unit weight.

under optimum compaction conditions. Such a high value when compared to clays with similar Atterberg limits and grain size distribution curves may be explained by the porous microstructure of lateritic soils. Furthermore, it must be remembered that laboratory tests underestimate the permeability of in situ compacted layers [8]. The soil can be compacted at a higher energy to a higher dry unit weight and lower k-value, as already observed in field compaction. However, the consequent rigidity of the liner must be evaluated since it will increase cracking by differential settlement.

Permeability of this soil depends drastically on moulding water content and compaction degree, being more influenced by compaction degree than by water content, and showing variations of three orders of magnitude for the range of tested compaction conditions. The relevance of this conclusion is enhanced by the experimental evidence that deviations from the specifications usually occur in the field, even when compaction is well controlled, and that significant spacial variation of permeability is the rule for compacted soil layers [2].

\subsection{Compatibility Tests}

The results in Figure 7 show a rise in $\mathrm{w}_{\mathrm{L}}$ and a slight decrease in $\mathrm{w}_{\mathrm{P}}$ for all the studied metals except mercury, for which $w_{P}$ also rose. With exception of mercury, PI increased significantly for all metals, due mainly to $\mathrm{w}_{\mathrm{L}}$, probably because of the dispersion caused by the polyvalent ions. For mercury, PI remained constant, because $\mathrm{w}_{\mathrm{L}}$ and $\mathrm{w}_{\mathrm{P}}$ increased by the same amount.

\subsection{Diffusion Tests}

Lateritic soils are highly enriched with iron and aluminum oxides and hydroxides throughout the intense weathering, which is a characteristic of the process of soil formation known as laterization. These oxi-hydroxides occur as "concretions", assembling clay particles in arrangements usually regarded as physically and chemically stable. Pure diffusion through the soil of the metal ions utilized in the tested solutions seem to be accompanied by more complex phenomena derived from the contact of the concretions with an acidic environment. This speculation arises, for example, by Figure 8, which shows the measured concentration of aluminum in the fluid reservoir for five specimens compacted statically at standard Proctor optimum conditions, each topped by a different synthetic solution. The initial solutions had $\mathrm{pH}$ values ranging from 1 to 2 . It should be pointed out that aluminum was present in just one of these solutions, and that its initial concentration in the specimen pore water was below $1 \mu \mathrm{g} / \mathrm{g}$. Repeatability of the results of Figure 8 was verified in 32 different tests.

Mass balance indicated that the amount of aluminum that entered the reservoir from the soil could not be explained in terms of desorption alone, suggesting the occurrence of dissolution phenomena due to the acidic $\mathrm{pH}$. Peak values varied for each tested solution, but no correlation was found between peak value and initial aluminum concentration, initial ionic concentration or $\mathrm{pH}$ value.

The same behavior was observed for iron, manganese and zinc, which are soil constituents. Cadmium and mercury, which do not exist originally in the soil particles according to X-ray fluorescence test, showed the expected behaviour for diffusion tests, as shown in Figure 9.

Compaction variations showed no sensible influence on diffusion. Figure 10, for example, shows the variation of cadmium concentration in the reservoir with time for four specimens at different relative compactions topped with the same solution.

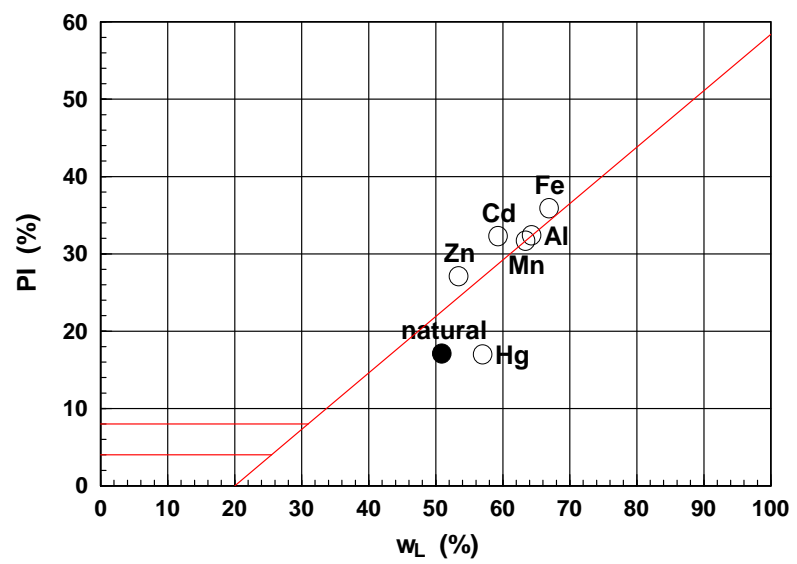

Figure 7. Atterberg limits with addition of metals. 


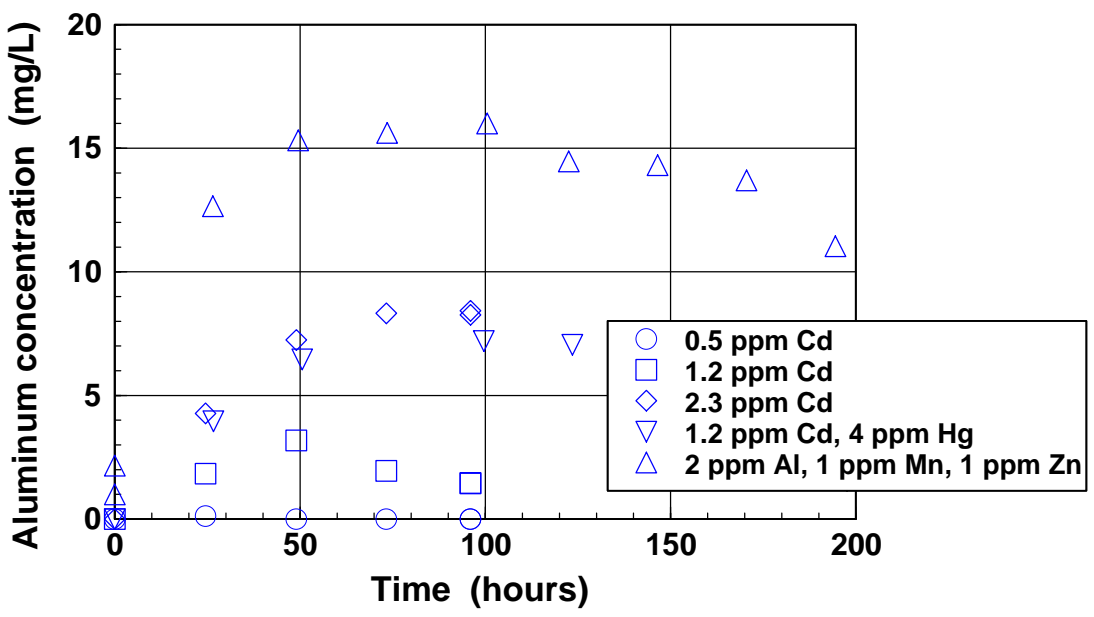

Figure 8. Aluminum concentration in the fluid reservoir.

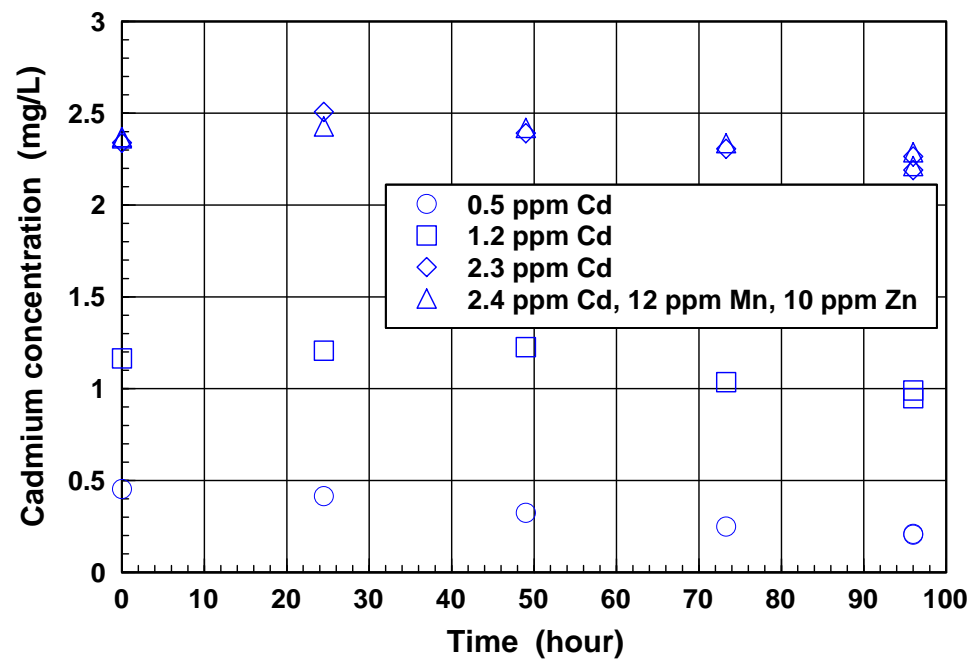

Figure 9. Cadmium concentration in the fluid reservoir.

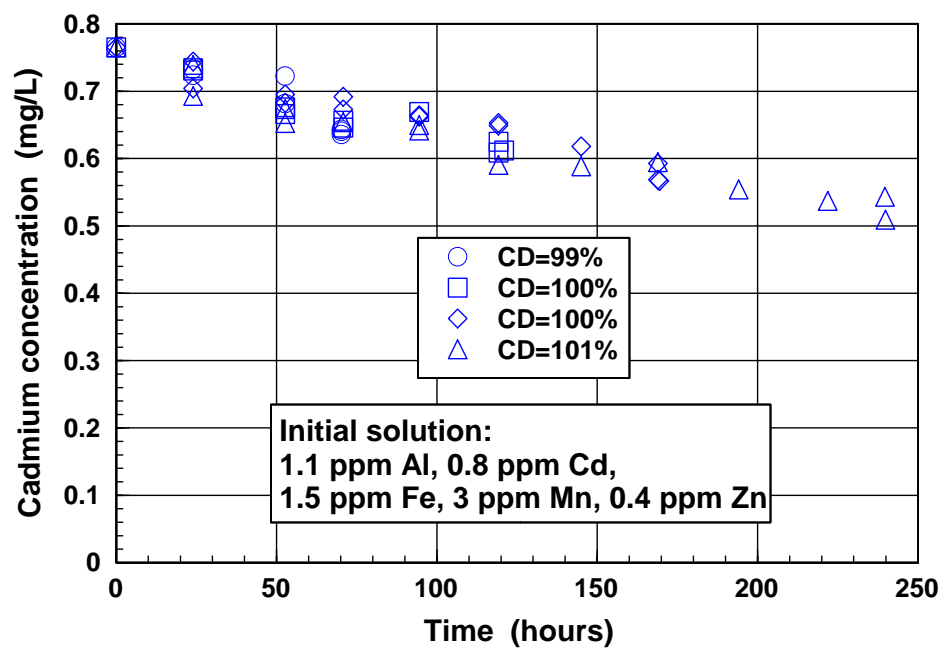

Figure 10. Influence of compaction degree on the diffusion behaviour. 
Batch tests indicate a low adsorption capacity for cadmium, as might be expected from the soil mineralogy: kaolinite is the predominant clay mineral. Fitting the linear model to experimental results yielded $\mathrm{K}_{\mathrm{d}}$ values of 13 $\mathrm{mL} / \mathrm{g}$ for low concentrations, and $0.2 \mathrm{~mL} / \mathrm{g}$ for concentrations higher than $6 \mathrm{mg} / \mathrm{L}$. Mass balance from diffusion tests, on the other hand, suggests $K_{d}$ values of about 1 to $2 \mathrm{~mL} / \mathrm{g}$ when adsorption in the whole probe is considered, whereas the assumption of adsorption equilibrium with the upper layer of the probe leads to $K_{d}$ values of 4 to 10 $\mathrm{mL} / \mathrm{g}$. Freundlich equation fitting for cadmium may be expressed by:

$$
\mathrm{S}=19.2 \mathrm{C}^{0.53}(\mathrm{~mL} / \mathrm{g})
$$

where $\mathrm{S}$ is the adsorption degree (mass of adsorved solute/dry mass of soil) and $C$ is the equilibrium concentration (mass of dissolved solute/solution volume)

\subsection{Mineralogical Tests}

Mineralogical tests were carried out in order to verify the occurrence of solubilization of aluminum from soil particles, i.e. from aluminum oxides and hydroxides, as indicated by the results of diffusion and batch tests. Samples from the natural soil and from probes previously tested to diffusion were submitted to X-ray diffraction tests, X-ray fluorescence tests and scan electron microscopy tests. Figure 11 shows conglomerates of kao linite particles bonded by iron/aluminum oxides in the natural soil and after days of contact with a metal solution with $\mathrm{pH} 2$. Leaching of the conglomerate is visible: contours of kao linite particles are clearer after part of the cementing oxides was removed from the soil.

\section{Conclusions}

The consideration of the pollution transport through the soils is very important for the improvement of the design of waste disposal sites. More research is necessary to use all potentialities of lateritic soils, one of the most frequently and extensively used type of soil for compacted fills in Brazil, for clay liners. Advection can be the dominant phenomenon, since drastic variations in permeability can result from small deviations from the specified compacted conditions. More investigations are needed to account for the chemical reactions that may take place when such soils are exposed to acidic solutions, and that might turn out to be as significative as the diffusion and adsorption mechanisms.

\section{Acknowledgments}

The authors would like to FAPESP (Foundation for Research Support of the State of São Paulo) for the finantial support. Physical-chemical analyses of the Tietê River

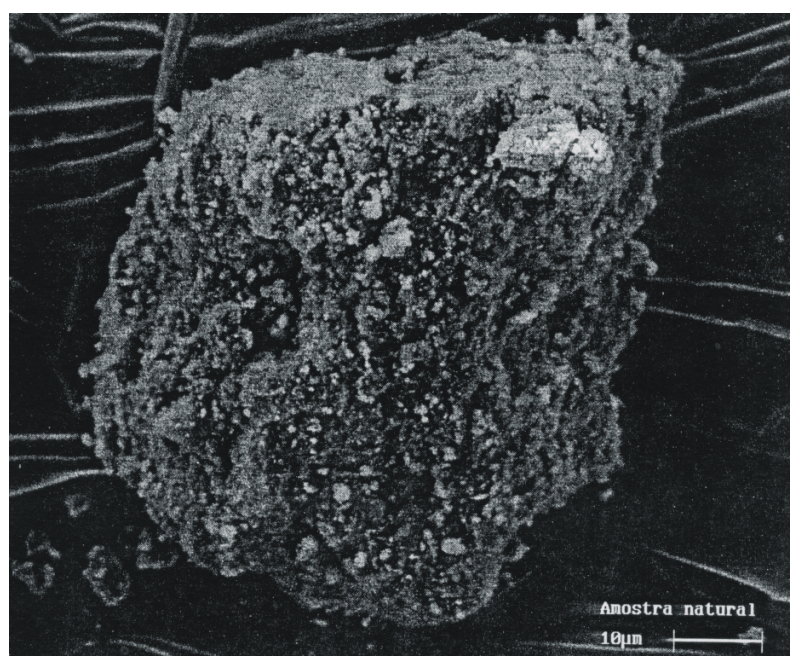

(a)

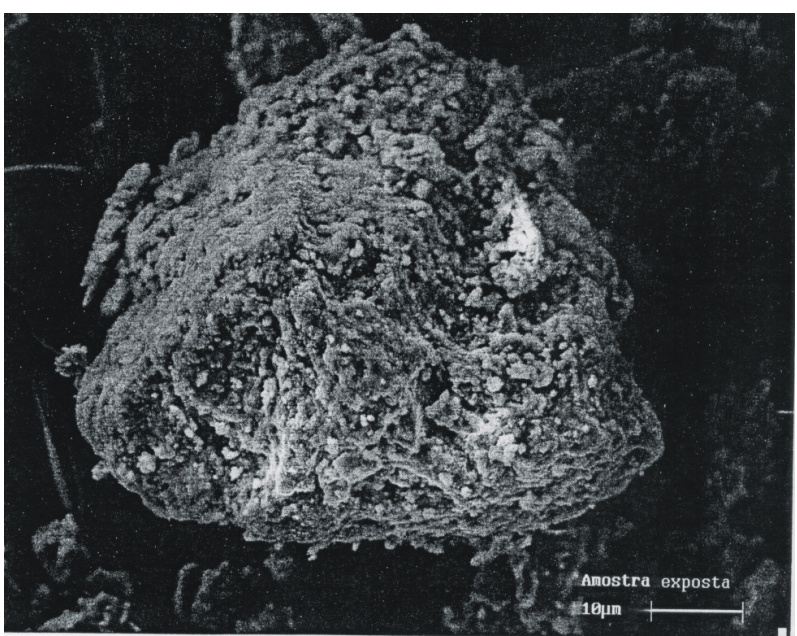

(b)

Figure 11. Kaolinite-oxides conglomerates: a. natural soil; b. after a diffusion test in acidic environment.

sediments were kindly bestowed by Dr. Dione Morita. Access to data related to managament and disposal sites of the Tietê River sediments was granted by DAEE (Water Resources and Energy Department of the State of São Paulo). The mineralogical tests were performed at the Technological Characterization Laboratory of the Mining Engineering Department of the Polytechnic School of São Paulo.

\section{REFERENCES}

[1] F. S. Barone, E. K. Yanful, R. M. Quigley and R. K. Rowe, "Multiple Contaminant Migration on Diffusion and Adsorption of Some Domestic Wastes Contaminants in a Natural Clayey Soil," Canadian Geotechnical Journal, Vol. 26, No. 2, 1989, pp. 189-198. doi:10.1139/t89-028

[2] C. H. Benson and D. E. Daniel, "Minimum Thickness of 
Compacted Soil Liners: I. Stochastic Models,” Journal of Geotechnical Engineering, Vol. 120, No. 1, 1994, pp. 129-152. doi:10.1061/(ASCE)0733-9410(1994)120:1(129)

[3] L. L. B. Bernucci, "Considerações Sobre o Dimensionamento de Pavimentos Utilizando Solos Lateríticos para Rodovias de Baixo Volume de Tráfego,” Ph.D Thesis, Escola Politécnica da Universidade de São Paulo, São Paulo, 1995.

[4] M. E. G. Boscov, "Contribuição ao Projeto de Sistemas de Contenção de Resíduos Perigosos Utilizando Solos Lateríticos,” Ph.D Thesis, Escola Politécnica da Universidade de São Paulo, São Paulo, 1997.

[5] M. E. G. Boscov, "Brazilian Experience in Geo-Environmental Applications of Tropical Soils 6ICEG," Proceedings of 6th International Congress on Environmental Geotechnics, New Delhi, 2010, pp. 328-341.

[6] P.T. Cruz, "100 Barragens Brasileiras. Casos Históricos. Materiais de Construção,” Oficina de Textos, São Paulo, 1996.

[7] CTH—Centro Tecnológico de Hidráulica, "Disposição dos Sedimentos Dragados do Rio Tietê. Caracterização bioquímica,” Internal Report, São Paulo, 1994.

[8] D. E. Daniel, "Predicting Hydraulic Conductivity of Clay Liners,” Journal of Geotechnical Engineering, Vol. 110, No. 2, 1984, pp. 285-300. doi:10.1061/(ASCE)0733-9410(1984)110:2(285)

[9] R. A. Freeze and J. A. Cherry, "Groundwater," Pren-
tice-Hall, Upper Saddle River, 1979.

[10] IBGE-Brazilian Institute of Geography and Statistics, “National Survey on Basic Sanitation," 2010. http://www.ibge.gov.br/home/estatistica/populacao/condicaodevida/pnsb2008/default.shtm.

[11] ISSMFE-International Society for Soil Mechanics and Foundations Engineering, "Peculiarities of Geotechnical Behavior of Tropical Lateritic and Saprolitic Soils,” Progress Report, Committee on Tropical Soils, São Paulo, 1985.

[12] R. Meriggi and A. Zagolin, "Hydraulic Conductivity of a Waste Silty Clay,” Proceedings of VII IAGE Conference, 1994, pp. 2363-2369.

[13] D. M. Morita, “Tratabilidade de Águas Residuárias Contendo Poluentes Perigosos: Estudo de Caso,” Ph.D Thesis, Escola Politécnica da Universidade de São Paulo, São Paulo, 1993.

[14] J. S. Nogami and D. F. Villibor, "Peculiaridades dos solos Lateríticos nas Pavimentações de Baixo Volume de Tráfego,” Proceedings of I International Symposium on Low Volume Roads, Rio de Janeiro, 1997, pp. 542-560.

[15] R. K. Rowe, R. M. Quigley and J. R. Booker, "Clayey Barrier Systems for Waste Disposal Facilities,” Chapman \& Hall, London, 1995.

[16] USEPA, "Batch-Type Procedures for Estimating Soil Adsorption of Chemicals," Technical Resource Document, EPA/530-SW-87-006-F, 1992. 